\title{
Molecular Phylogenetics of the Dragon's Blood Croton Section Cyclostigma (Euphorbiaceae): A Polyphyletic Assemblage Unraveled
}

\author{
Ricarda Riina, ${ }^{1,2,4}$ Paul E. Berry, ${ }^{2}$ and Benjamin W. van Ee ${ }^{1,3}$ \\ ${ }^{1}$ Department of Botany, University of Wisconsin-Madison, 430 Lincoln Dr., Madison, Wisconsin 53706 U.S.A. \\ ${ }^{2}$ University of Michigan Herbarium and Department of Ecology and Evolutionary Biology, 3600 Varsity Drive, \\ Ann Arbor, Michigan 48108 U.S.A. \\ ${ }^{3}$ Harvard University Herbaria, 22 Divinity Avenue, Cambridge, Massachusetts 02138 U.S.A. \\ ${ }^{4}$ Author for correspondence (riina@umich.edu) \\ Communicating Editor: Alan W. Meerow

\begin{abstract}
The phylogenetic relationships of Croton section Cyclostigma sensu Webster were examined using nuclear ribosomal ITS and plastid spacer $\operatorname{trn} L-F$ sequences from 48 of the 63 species in the group, including members of the four recognized subsections and representing the group's full morphological and geographic range. The two gene phylogenies concurred that section Cyclostigma sensu Webster is polyphyletic, with its members appearing in nine different clades throughout Croton. The clade that retains the taxonomic type of the section and about half of the species sampled is redefined here as a reduced, monophyletic section Cyclostigma, and the remaining species are placed in other sections or informal clades. The ITS and chloroplast phylogenies are discordant regarding the position of the redefined section Cyclostigma suggesting that reticulate evolution might have played a role in the evolutionary history of this group. These results highlight that the tree habit has evolved on multiple occasions in Croton, and that there are other morphological characters that can effectively distinguish different tree lineages in the genus.
\end{abstract}

Keywords-Conflicting gene histories, ITS, Medicinal plants, Neotropics, Sangre de Drago, trnL-F

The taxonomy and systematics of Croton L. (Euphorbiaceae s. s.) have proven to be problematic due to the large size of the genus ( 1,300 species), its wide geographical range (tropics and subtropics worldwide), and the lack of distinct morphological synapomorphies for its constituent sections. Croton species are easily recognized in the field by a suite of characters including conspicuous stellate or lepidote trichomes, narrow or condensed thyrsoid inflorescences of unisexual flowers, clear or colored sap, frequent petiolar glands, and senescent leaves that turn orange before absciscing. The shrubby habit predominates across the genus, but trees and herbs are also well represented. The first molecular phylogenetic studies of Croton and tribe Crotoneae indicated that the genus is monophyletic after the exclusion of the former sect. Astraea (Klotzsch) Baill., and inclusion of the segregate genera Crotonopsis Michx., Cubacroton Alain, Eremocarpus Benth., Julocroton Mart., and Moacroton Croizat (Berry et al. 2005; van Ee et al. 2008).

The most recent sectional classification of Croton proposed by Webster (1993) divided the genus into 40 sections. Croton sect. Cyclostigma Griseb. (Webster 1993) was defined by the presence of bisexual cymules in the inflorescences (i.e. staminate flowers associated with the pistillate ones at the lower nodes of the inflorescence), stellate pubescence, reddish sap, and a shrubby to arborescent habit. Following Webster's circumscription, the section consisted of about 60 species distributed in lowland and montane areas of Mexico, Central and South America, and a few species from mainland Africa and Madagascar (Table 1). Webster (1993) initially divided Cyclostigma into three subsections: subsect. Cyclostigma (Griseb.) Müll. Arg., subsect. Sampatik G. L. Webster, and subsect. Palanostigma Mart. ex Baill. Subsequently, Webster (2001) established a fourth subsection, Xalapenses G. L. Webster, with three species from Mexico and three from South America; these species are small to robust shrubs lacking the main character defining the section (bisexual lower cymules). The classification of Webster (1993) incorporated and expanded Grisebach's sect. Cyclostigma and Baillon's subsect. Palanostigma, both of which have basal bisexual cymules (Baillon 1858; Grisebach 1859). Webster's morphological dis- tinction of the four Cyclostigma subsections is based on a suite of morphological characters, most of which do not provide a clear separation between the subsections (Table 1).

Members of sect. Cyclostigma sensu Webster $(1993,2001)$ are fast-growing trees and shrubs occurring predominantly in disturbed sites such as roadsides, stream and river edges, and mountain landslide areas. Most members of the section grow in moist forest habitats, but some of the small shrubby species (subsect. Xalapenses) grow in open and dry vegetation. These ecological characteristics make most of the members of this group ideal candidates for restoration of degraded forests. For example, Croton urucurana Baill. is currently used in restoration of degraded river basins in southern Brazil (Lorenzi 1992; Carrenho et al. 1997), and it is also used for urban areas and city parks in some Brazilian cities. Croton mutisianus Kunth and C. bogotanus Cuatrec. have similar uses as ornamental trees in some Colombian cities. The wood of several species is also used for boat and house construction, for charcoal, and for carpentry and cabinet making (Lorenzi 1992; Smith 2002). However, the most popular uses of these trees are for the medicinal properties of their latex (Ubillas et al. 1994; Meza 1999; Borges and King 2000; Jones 2003). Several species of Croton sect. Cyclostigma (especially Croton lechleri Müll. Arg.) are commonly known as "sangre de drago" (dragon's blood) because of the blood-red latex, and are used for domestic purposes in indigenous and rural communities, primarily for treating cuts to prevent infection and to accelerate wound-healing (Ubillas et al. 1994; Jones 2003).

The only recent taxonomic treatment for sect. Cyclostigma was for a small group of 12 species from Ecuador, as part of a doctoral dissertation by B. Smith (2002). Interestingly, he could not identify any morphological synapomorphies for the group as a whole. For example, other sections in Croton besides sect. Cyclostigma have basal bisexual cymules (sections Cleodora (Klotzsch) Baill., Eutropia (Klotzsch) Baill. and Luntia (Raf.) G.L. Webster), and stellate pubescence is widespread across the genus. Webster (1993) admitted that the use of bisexual cymules as a diagnostic character for Croton sections is dubious due to the lack of consistency of the character within species. 
TABle 1. Members of Croton sect. Cyclostigma s. 1. (63 spp.), subsectional classification, and diagnostic characters of each subsection sensu Webster $(1993,2001)$ and Smith (2002). Species included in our molecular sampling (48 spp.) are indicated with asterisks.

\author{
Section / Subsections / Diagnostic characters
}

Croton sect. Cyclostigma Griseb.

Monoecious trees or shrubs; indumentum stellate; stems often exuding reddish sap; leaves alternate, mostly palmately veined or lobed, less often pinnately veined, biglandular to multiglandular at base, glands sessile or stipitate, rarely lacking; inflorescence terminal, bisexual basal cymules usually present; petals present in staminate flowers, usually reduced in pistillate flowers; stamens 11-100 or more; pistillate flowers distinctly pedicellate, sepals entire, eglandular, valvate or reduplicate-valvate; styles bifid to multifid

subsect. Cyclostigma

Leaves palmately or pinnately veined, subentire or denticulate, copiously stellate beneath; stamens 15-65; calyx of pistillate flower not reduplicatevalvate; styles bifid.

\author{
Mexico and Central America \\ ${ }^{*}$ C. draco Cham. \& Schltdl. \\ ${ }^{*}$ C. verapazensis Donn. Sm. South America \\ ${ }^{*}$ C. abutiloides Kunth \\ ${ }^{*}$ C. aequatoris Croizat \\ ${ }^{*}$ C. anisodontus Müll. Arg. \\ ${ }^{*}$ C. ater Croizat \\ ${ }^{*}$ C. densiflorus Pax \& K.Hoffm. (= C. piluliferus Rusby) \\ ${ }^{*}$ C. draconoides Müll. Arg. \\ ${ }^{*}$ C. echinocarpus Müll. Arg.
}

$$
\begin{aligned}
& { }^{*} \text { C. floccosus B.A. Smith } \\
& { }^{*} \text { C. gossypiifolius Vahl } \\
& { }^{*} \text { C. gracilipes Baill. } \\
& { }^{*} \text {. hibiscifolius Kunth } \\
& { }^{*} \text { C. huberi Steyerm. } \\
& \text { *C. lechleri Müll. Arg. } \\
& { }^{*} \text { C. macrobothrys Baill. } \\
& \text { *C. magdalenensis Müll. Arg. } \\
& { }^{*} \text { C. mutisianus Müll. Arg. } \\
& \text { *C. perspeciosus Croizat } \\
& \text { C. polycarpus Benth. } \\
& { }^{*} \text { C. purdiei Müll. Arg. } \\
& { }^{*} \text { C. redolens Pittier }
\end{aligned}
$$

\author{
${ }^{*}$ C. ruizianus Müll. Arg. \\ ${ }^{*}$ C. sarcopetalus Müll. Arg. \\ C. sarcopetaloides S. Moore \\ ${ }^{*}$ C. urucurana Baill. \\ Africa and Madagascar \\ C. draconopsis Müll. Arg. \\ C. congensis de Wild. \\ C. pynaertii de Wild. \\ C. wellensii de Wild. \\ ${ }^{*}$ C. mongue Baill. \\ ${ }^{*}$ C. oreades Leandri
}

subsect. Sampatik G. L. Webster

Leaves pinnately veined, crenate, sparsely appressed-stellate; stamens 10-20; pistillate flowers long-pedicellate; sepals of pistillate flower not reduplicate-valvate; styles bifid.
South America
${ }^{*}$ C. sampatik Müll. Arg.
${ }^{*}$ C. organensis Baill.
${ }^{*}$ C. piptocalyx Müll. Arg.
${ }^{*}$ C. priscus Croizat
${ }^{*}$ C. echioides Baill.
${ }^{*}$ C. cordiifolius Baill.

subsect. Palanostigma Mart. ex Baill.

Leaves mostly palmately veined and copiously stellate beneath; stamens 10-100+; pistillate flowers distinctly pedicellate, sepals \pm reduplicate-valvate; styles multifid.
South America
C. caldensis Müll. Arg.
${ }^{*}$ C. callicarpiifolius Vahl (= C. huberi Steyerm.)
${ }^{*}$ C. celtidifolius Baill.
${ }^{*}$ C. chocoanus Croizat
${ }^{*}$ C. coriaceus Kunth
C. huitotorum Croizat
C. killipianus Croizat
${ }^{*}$ C. lagoensis Müll. Arg.
${ }^{*}$ C. medusae Müll. Arg.
C. nuntians Croizat
${ }^{*}$ C. palanostigma Klotzsch
C. quadrisetosus Lam.
${ }^{*}$ C. rimbachii Croizat

\author{
${ }^{*}$ C. smithianus Croizat \\ ${ }^{*}$ C. speciosus Müll. Arg. \\ ${ }^{*}$ C. warmingii Müll. Arg. \\ Madagascar \\ C. chypreae Leandri \\ ${ }^{*}$ C. goudotii Baill.
}

subsect. Xalapenses G. L. Webster

Leaves palmately veined with dense stellate pubescence; stamens 12-35; basal cymules with female flowers only, female flowers sessile or subsessile; styles bifid; petiolar glands sometimes lacking.
Mexico and C. America
C. stenopetalus G.L. Webster
${ }^{*}$ C. xalapensis Kunth
${ }^{*}$ C. suberosus Kunth
South America
C. boliviensis Müll. Arg.
${ }^{*}$ C. chilensis Müll. Arg.
${ }^{*}$ C. pungens Jacq.

Berry et al. (2005) included 19 species of Croton sect. Cyclostigma sensu Webster (1993) in the first molecular study of the genus. Their phylogenetic analysis recovered these species as part of two sister clades in a combined analysis of ITS and $t r n L-F$ data; one of these clades included several of the sampled Cyclostigma species intermixed with species of sect. Cascarilla Griseb. (including former sect. Velamea Baill.).

In this study we analyze ITS and trnL-F sequence variation of many more representatives of Croton sect. Cyclostigma sensu Webster (1993) using maximum parsimony, maximum likelihood, and Bayesian approaches. Several other species representing different Croton lineages relevant for our study, and two nonCroton species as the outgroup, were also included in the analyses. Our goals were to (a) test the molecular support for Croton sect. Cyclostigma sensu Webster, particularly the monophyly and the relationships of the four subsections proposed by Webster (1993); (b) identify the closest relatives to sect. Cyclostigma within Croton; and (c) provide a new circumscription of a monophyletic Croton sect. Cyclostigma sensu stricto and identify the morphological characters that best separate this group from the rest of Croton.

\section{Material AND Methods}

Taxon Selection and Sampling Approach-A preliminary data set including a larger taxon sampling across Croton was analyzed using maximum parsimony (results not shown here) in PAUP* (Swofford 2002). This initial data set included all the sampled members of sect. Cyclostigma (Table 1) and representatives of all 40 sections of Croton sensu Webster (1993). This approach allowed us to select only a few species from most of the Croton lineages as clade placeholders and thus have a data set we could analyze more thoroughly. Our final reduced ITS and $\operatorname{trn} L-F$ data matrices contain 48 (37 trnL-F and 47 ITS sequences) out of the 63 species belonging to Croton sect. Cyclostigma sensu Webster (1993, 2001; 
Table 1), with representatives from all four subsections, and spanning most of the section's geographical range, including several Old World Cyclostigma species. In addition, one or two representatives of many other Croton clades were selected from the initial large data set to serve as placeholders, and two taxa were used as outgroups (Brasiliocroton mamoninha P.E. Berry \& Cordeiro and Astraea lobata (L.) Klotzsch), following the current Croton molecular phylogenetic hypothesis (Berry et al. 2005). A list of the 83 species used in this study with authorities, voucher information, GenBank accession numbers, and sample sources is provided in Appendix 1.

DNA Sequencing and Alignment-DNA was extracted from live, silica-dried, and herbarium tissue of single individuals using DNeasy Plant Mini kits (Qiagen, Valencia, California). The ITS region was amplified using the primers ITS-I (Urbatsch et al. 2000) and ITS4 (White et al. 1990). Internal primers ITS3 and ITS4 (White et al. 1990) were used when DNA amplification failed with the first pair of primers, which happened often with herbarium samples. The cpDNA trnL intron and trnL-F intergenic spacer were amplified using primers " $c$ " and " $\mathrm{f}$ " of Taberlet et al. (1991); for herbarium material, amplification was performed in two segments, using primers " $\mathrm{c}$ " and " $\mathrm{d}$ " for the trnL intron and primers " $\mathrm{e}$ " and " $\mathrm{f}$ " for the trnL-trnF spacer.

Polymerase chain reaction (PCR) amplification of the selected markers used $25 \mu \mathrm{L}$ reactions containing $0.2 \mu \mathrm{L}$ of 5 units $/ \mu \mathrm{L}$ Takara Ex Taq DNA polymerase, $2.5 \mu \mathrm{L} 10 \times$ Ex Taq Buffer, $3 \mu \mathrm{L}$ dNTP mixture $(2.5 \mathrm{mmol} / \mathrm{L}$ each), $1.25 \mu \mathrm{L}$ DMSO, $0.25 \mu \mathrm{L} 0.4 \%$ bovine serum albumin (BSA), $0.5 \mu \mathrm{L}$ each primer $(20 \mathrm{mmol} / \mathrm{L}), 15.8 \mu \mathrm{L} \mathrm{ddH_{2 }} 0$, and $1 \mu \mathrm{L}$ of template DNA. The PCR profile consisted of an initial $1.5 \mathrm{~min}$ premelt at $94^{\circ} \mathrm{C}$ and 35 cycles of 0.5 min denaturation at $94^{\circ} \mathrm{C}, 1 \mathrm{~min}$ annealing at $48^{\circ} \mathrm{C}$, and $1.5 \mathrm{~min}$ extension at $72^{\circ} \mathrm{C}$, followed by a final extension of $7 \mathrm{~min}$ at $72^{\circ} \mathrm{C}$. PCR products were cycle-sequenced in $10 \mu \mathrm{l}$ reactions using BigDye reaction kits and the same primers used for PCR. Cycle sequencing products were cleaned with magnetic beads and sequenced on ABI 377 or ABI 3100 automated sequencers at the University of Wisconsin-Madison Biotechnology Center. Sequences were edited and assembled using the Staden Package Version 2003.0b1 (Staden 1996), and then manually aligned using Sequence Alignment Editor V2.0a11 (Rambaut 1996-2002) or MacClade 4.03 (Maddison and Maddison 2001). Alignment of these data sets was facilitated by our broader sampling of Croton, other members of tribe Crotoneae, and other Euphorbiaceae. The ITS sequences were analyzed with the recombination detection methods RDP (Martin and Rybicki 2000), MaxChi (Maynard Smith 1992), and GENECONV (Padidam et al. 1999) using the default settings of the program RDP3. The data matrices are archived in TreeBASE (study number S2154), and sequences are deposited in GenBank (Appendix 1).

Molecular Phylogenetic Analyses-Incongruence between trnL-F and ITS was evaluated using the incongruence length difference test (ILD; Farris et al. 1994) as implemented in PAUP* (Swofford 2002). One thousand data partition replicates were subject to maximum parsimony analysis using simple addition, heuristic searches with TBR branch-swapping. Uninformative and gapped characters were excluded. In addition, the Templeton test (Templeton 1983) was used to test alternative tree topologies, as implemented in PAUP* 4.0b10 (Swofford 2002) under a maximum parsimony framework.

Maximum parsimony (MP) analyses were conducted using PAUP* $4.0 \mathrm{~b} 10$ (Swofford 2002). We performed MP heuristic searches with 1,000 random taxon addition replicates using TBR branch swapping and multrees in effect. All characters were equally weighted, and gaps were treated as missing data. In the case of the trnL-F data set, the parsimony search was not able to be completed because the large number of most parsimonious trees exceeded the computational capacity. We therefore limited each random taxon addition replicate to save no more than 1,000 shortest trees. We used the consensus tree of 1,000,000 shortest retained trees as a backbone constraint to search for trees of equal or shorter length incompatible with the strict consensus topology, following the strategy of Catalán et al. (1997) to ensure that the strict consensus tree adequately summarizes all detected most parsimonious trees. This search was conducted with 5,000 random taxon addition sequence replicates using TBR branch swapping and multrees in effect. MP bootstrap percentages (BP) for each clade were estimated using 1,000 bootstrap replicates with 100 random taxon addition TBR searches, multrees in effect, and limiting the number of trees retained in each random addition search to 100 .

The Akaike Information Criterion (AIC) was used in the program Modeltest 3.7 (Posada and Crandall 1998) to estimate the most appropriate model of DNA substitution for each data set. For the Bayesian phylogenetic analysis, the optimal models of sequence evolution were inferred using MrModeltest v. 2.2 (Nylander 2004) and AIC. The AIC has been shown to be a superior method of model selection than the hierarchical likelihood ratio test (Posada and Buckley 2004).
Maximum Likelihood (ML) analyses were conducted using the program GARLI version 0.951 (Zwickl 2006). We performed four independent heuristic searches in GARLI and compared the resulting tree topologies for consistency. Bayesian analyses were conducted using the program MrBayes 3.1.2 (Huelsenbeck and Ronquist 2001). We conducted two Markov chain Monte Carlo (MCMC) analyses, each consisting of four linked chains (sequential heat $=0.2$ ) run for 1,000,000 generations, and sampling every 50 generations. The burn-in period was estimated by visual examination of a likelihood-by-generation plot. After inspection for evidence of good mixing, a majority rule consensus tree with clade credibility values was obtained by combining the trees from both MCMC chains.

\section{Results}

Size and Structure of Molecular Data Sets-The length of the ITS sequences varied from 713 bases in Astraea lobata (outgroup) to 734 bases in C. pachypodus G. L. Webster. The aligned length of the ITS data set is 771 positions, of which 349 are variable characters, and 261 are parsimony informative. The percentage of missing characters for the ITS matrix was $2.7 \%$. Almost no ambiguous sites are found in the ITS sequences overall. The analysis of the ITS data set using the RPD, MaxChi and GENECONV methods did not detect any evidence of intragenic recombination. The length of the truL$F$ sequences varied from 909 bases in Astraea lobata (outgroup) to 1080 bases in $C$. huberi Steyerm. The aligned trnL-F matrix is 1,222 bp long, and has 344 variable characters of which 178 are parsimony informative. The percentage of missing data for the $\operatorname{trn} L-F$ matrix was $8.4 \%$. These data sets differed in their taxon sampling, with 83 accessions for ITS and 75 for trnL-F (Appendix 1). The missing sequences are primarily from samples extracted from herbarium material that could not be amplified successfully for one of the two markers. The trnL-F data matrix includes only one species not sequenced for ITS (Croton draconoides Müll. Arg.), and lacks nine species included in the ITS data set: C. ater Croizat, C. lagoensis Müll. Arg., C. magdalenensis Müll. Arg., C. mongue Baill., C. oreades Leandri, C. redolens Pittier, C. smithianus Croizat, C. verapazensis Donn. Sm., and C. xalapensis Kunth. The trnL-F sequences have numerous indels and some of them were parsimony informative. We coded the indels and analyzed the matrix using parsimony, but the clades that they supported were already highly supported when using the nongap coded data, thus the indel coding was dropped from the final analyses.

Analysis of Chloroplast trnL-F Region-The parsimony search of the trnL-F data set retained 1,000,000 trees with Length $(\mathrm{L})=540(\mathrm{CI}=0.752$, and RI $=0.830$; both $\mathrm{CI}$ and RI were calculated including parsimony uninformative characters). No shorter trees were found after a second search using the strict consensus tree from the search above as a backbone constraint as described in the methods, nor was any tree of the shortest length found that was incompatible with the initial strict consensus.

For this data set the general time reversible model (GTR + $\mathrm{I}+\Gamma$ ) model was selected for both maximum likelihood and Bayesian analyses. All three analytical approaches performed on this data set (MP, ML, BA) recovered a polyphyletic sect. Cyclostigma s. 1. with almost half of its species resolved in several different Croton lineages, as shown in the ML tree (Fig. 1). From here on, "sect. Cyclostigma s. 1." refers to the taxonomic circumscription of Webster (1993; see Table 1), and "sect. Cyclostigma s. s.," or simply "the Cyclostigma clade," refers to the monophyletic clade that retained the majority of the species, including the type of the section (C. gossypiifolius Vahl). 


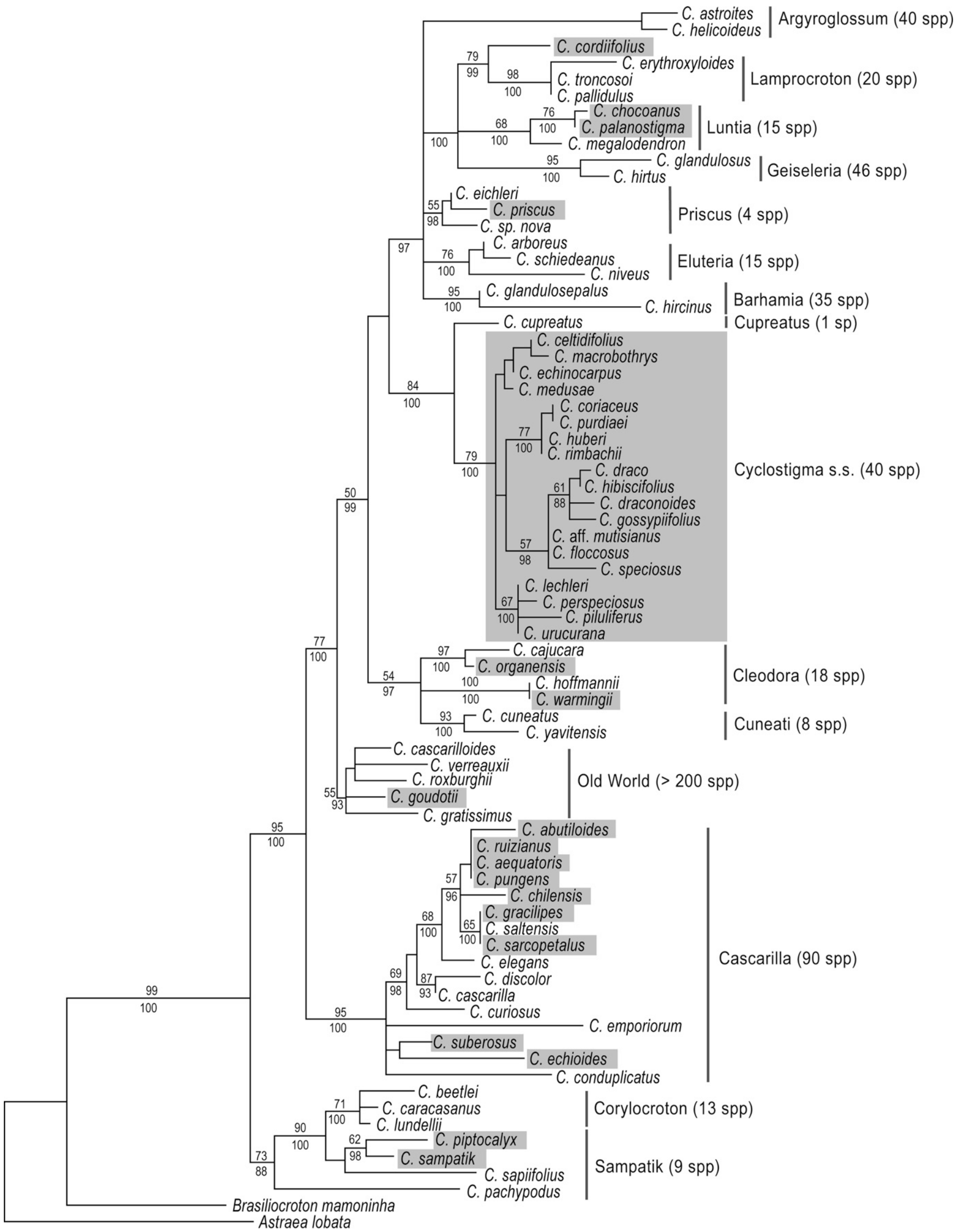

\subsection{5 substitutions/site}

FIG. 1. Maximum likelihood tree obtained from analyses of $t r n L-F$ data; parsimony bootstrap percentages $(\mathrm{BP})>50 \%$ are above branches and Bayesian posterior probabilities (PP) are below branches. Species with a gray background are members of section Cyclostigma s. 1. Main Croton clades are indicated with gray vertical bars (in most cases clade names correspond to Webster's names for sections or subsections). 
The trnL-F data supports C. cupreatus Croizat as the sister group of sect. Cyclostigma s. s. with $84 \%$ parsimony bootstrap percentage (BP) support and 1.00 Bayesian posterior probability (PP). The Cyclostigma clade is well supported with $79 \%$ parsimony BP and 1.00 Bayesian PP. Along with C. cupreatus it is sister to a highly diversified group including at least seven Croton clades or sections (Barhamia (Klotzsch) Baill., Eluteria Griseb., Priscus clade, Geiseleria (Klotzsch) Baill., Luntia, Lamprocroton (Müll. Arg.) Pax, and Argyroglossum Baill.; Fig. 1). The reduced sect. Cyclostigma s. s. consists of a polytomy of at least three clades, and this configuration was recovered by the three different analyses (MP, ML, BA).

Half of the species sampled that fall outside of the Cyclostigma clade ( $C$. abutiloides Kunth, $C$. aequatoris Croizat, $C$. chilensis Müll. Arg., C. pungens Jacq., C. ruizianus Müll. Arg., C. xalapensis, C. sarcopetalus Müll. Arg., and C. gracilipes Baill.) are shrubs less than 2 or $3 \mathrm{~m}$ tall. This phylogeny recovers these species as part of the sect. Cascarilla clade, one of the most species-rich lineages of Neotropical Croton (C-3 clade in Berry et al. 2005; Fig. 1). The Cascarilla clade (95\% BP, $1.00 \mathrm{PP})$ is sister to the large clade containing the Old World species and the majority of the New World clades, including Cyclostigma s. s. (Fig. 1).

The Old World representative of sect. Cyclostigma s. 1. included in the $\operatorname{trn} L-F$ data set, the Madagascan endemic C. goudotii Baill., also fell outside of the Cyclostigma clade (Fig. 1). All the Old World species sampled form a monophyletic group sister to the large New World clade that includes the Cyclostigma clade and ten other Croton clades or sections. Other members of sect. Cyclostigma s. 1. sampled for trnL-F are distributed among seven different Croton clades (see discussion).

Analysis of ITS-The MP search resulted in 24,992 most parsimonious trees $(\mathrm{L}=1,179, \mathrm{C} \mathrm{I}=0.465$, and $\mathrm{RI}=0.758$; both indexes were calculated including parsimony uninformative characters). The general time reversible model (SYM + I + Г) was selected for the maximum likelihood and Bayesian analyses. The results of the MP, ML, and BA of the ITS data matrix also recovered a highly polyphyletic sect. Cyclostigma s. 1., as depicted in the ML tree (Fig. 2).

Like the trnL-F phylogeny, all three analytical approaches (MP, ML, BA) performed on the ITS matrix recovered a polyphyletic sect. Cyclostigma s. 1. with more than half the sampled species coming out in nine different clades (Fig. 2). Similarly, one of these clades retained half of the sampled Cyclostigma s.l. including the type species. However, the ITS phylogeny shows a major difference in topology from the trnL-F phylogeny regarding the phylogenetic position of the Cyclostigma clade and its closest relatives within Croton. Contrary to the trnL-F phylogeny, in which C. cupreatus was sister to sect. Cyclostigma, the ITS data strongly supports sect. Cascarilla as the sister clade of Cyclostigma s. s., with 100\% BP and 1.00 PP (Fig. 2). Croton cupreatus is recovered sister to an assemblage of other New World sections that includes the same groups as shown in the combined ITS and trnL-F phylogeny in Berry et al. (2005, Fig. 5, clades C-5 to C-11).

The Old World taxa assigned to sect. Cyclostigma s. 1. are represented here by three species (C. goudotii, C. mongue, and C. oreades), and their positions outside the Cyclostigma clade corroborate the results of the trnL-F phylogeny. As in the trnL-F phylogeny, the Old World clade occupies the same position sister to the group formed by Cupreatus-Argyroglossum clades, only in this case the Cyclostigma clade is not part of that group.
The Cyclostigma clade is highly supported by the ITS data (100\% BS, $1.00 \mathrm{PP})$. As with the trnL-F phylogeny, the backbone of the Cyclostigma clade is not fully resolved by the ITS data. Although most of the Cyclostigma subclades recovered by ITS were also supported by the $\operatorname{rnL}-F$ data set, their topologies do not always correspond exactly when contrasting the two phylogenies.

Data Congruency-From our results it is clear that the main topological difference between the two gene phylogenies is the position of the Cyclostigma clade. This observation was confirmed by the results of the incongruence length difference (ILD) test (Farris et al. 1994) applied to the combined data set including all taxa for which both trnL-F and ITS sequences are available $(p=0.007)$.

We used the Templeton test to evaluate how the separate data sets support these two conflicting topologies. We constrained sect. Cascarilla to be sister to the Cyclostigma clade to see if the trnL-F data significantly rejects this phylogenetic relationship. The shortest tree compatible with this constraint was nine steps longer than the unconstrained tree, which was significant using the Templeton test $(p=0.0201)$. Then, using the ITS data set, we made a constraint to search for trees that do not have a Cascarilla + Cyclostigma s. s. clade. The Templeton test was not significant in this case $(p=0.0499-0.0974)$, so the ITS data does not reject a hypothesis in which Cascarilla and Cyclostigma are not sister to each other.

For this study we did not combine the trnL-F and ITS data sets because the separate gene phylogenies are sufficient to answer our initial questions about this group within Croton. Nonetheless, we conducted analyses on the combined data matrix to observe the resulting phylogenetic pattern (results not shown). As would be expected when combining data from different discordant gene regions, there is an increase in resolution in some parts of the phylogeny, and a decrease in support in others (due to the conflicting clades). Ultimately, the tree topology resulting from the combined data set is most similar to the topology of the ITS phylogeny. We also examined AT:GC nucleotide ratios across all species in our data sets and we did not find any pattern suggesting that the GC content is influencing the phylogenetic association of either C. cupreatus or sect. Cascarilla with the Cyclostigma clade.

\section{DisCUSSION}

Croton Section Cyclostigma in Light of Molecular Evidence-The sectional synopsis of Croton by Webster (1993) was without doubt an enormous contribution to the understanding of this complex and large genus. Webster's subdivision of the genus was based on general patterns of morphological similarities among species, but he did not find any obvious synapomorphies to support the individual sections. All the sections are defined by suites of morphological characters that are largely homoplasious across the genus. Our results here, together with other molecular phylogenetic studies of Croton (Berry et al. 2005; van Ee et al. 2008), show that many of Webster's sections, including Cyclostigma, are polyphyletic.

We use the ITS phylogeny to review the main patterns of phylogenetic relationships among the different taxa of sect. Cyclostigma s. 1., referring to the trnL-F phylogeny when necessary. The trees derived from MP, ML, and BA have compatible topologies, and we selected the ML tree to guide the discussion (Fig. 2). We assigned provisional names to clades using Webster's (1993) sectional nomenclature whenever his view 
Section Cyclostigma (Webster 1993, 2001)

- subsect. Cyclostigma

* subsect. Sampatik

- subsect. Palanostigma

+ subsect. Xalapenses
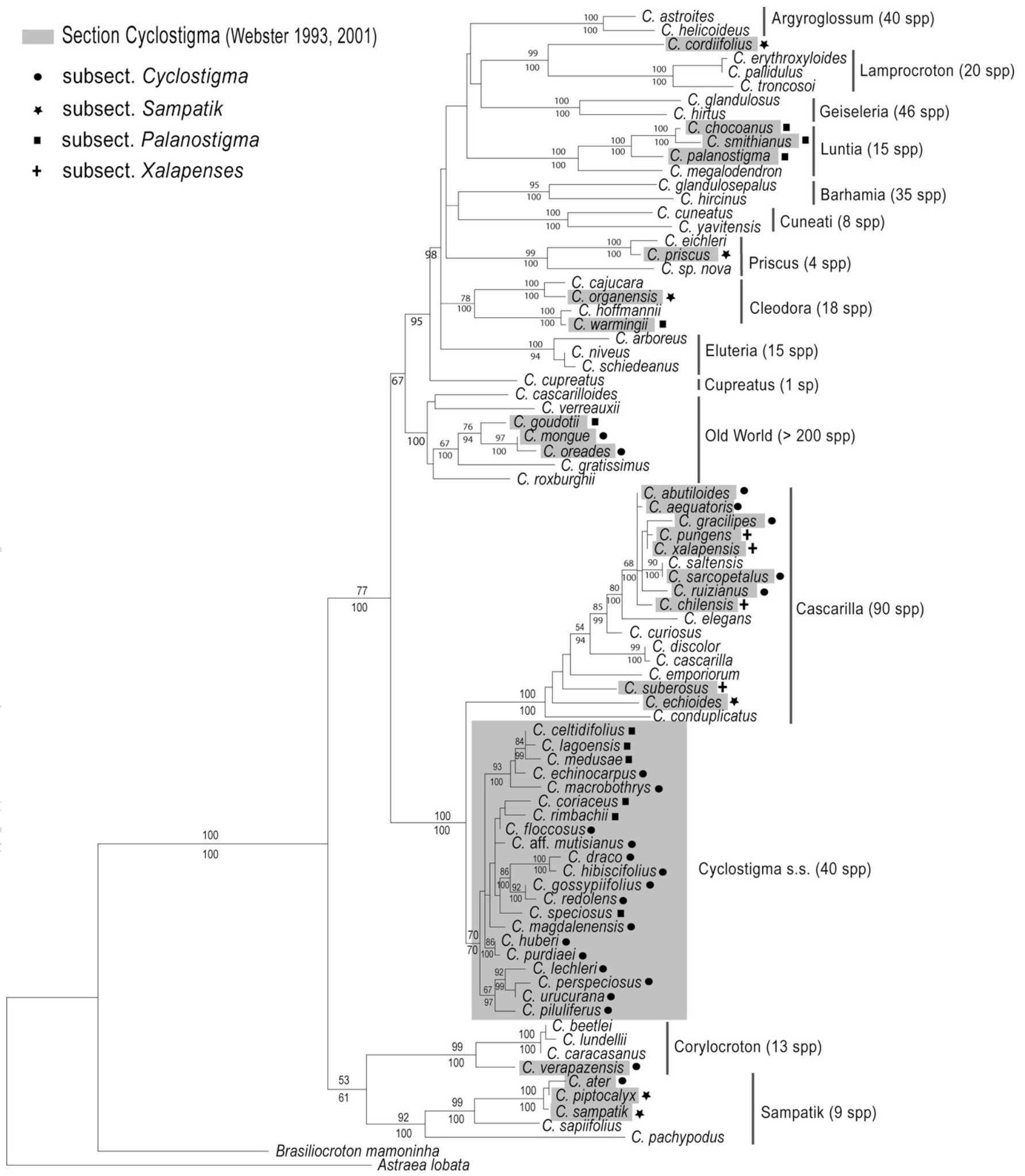

\subsection{1 substitutions/site}

FIG. 2. Maximum likelihood tree from ITS data; parsimony bootstrap percentages (BP) $>50 \%$ are above branches, and Bayesian posterior probabilities (PP) are below branches. Species with a gray background are member of sect. Cyclostigma s. 1. Main Croton clades are indicated with gray vertical bars (in most cases clade names correspond to Webster's names for sections or subsections). Webster's Cyclostigma subsections (Table 1) are also indicated with symbols to the right of each species name.

of a section was compatible with our phylogenetic results. We used the name of an included species to name additional novel clades. The Old World clade was the only one named after geographic distribution. Some of these clades were already identified by Berry et al. (2005), and others were identified by other studies within Croton (van Ee 2006; van Ee et al. 2008). Every lineage in this phylogeny, including the outgroup, is Neotropical, with the exception of the Old World clade. 
Our phylogenetic results indicate that sect. Cyclostigma sensu Webster is largely polyphyletic, with its members spread out in nine different clades (Fig. 2). Likewise, the subsectional subdivision of Webster mapped on the phylogeny shows a similar pattern of discordance (Fig. 2). Webster only defined subsections for two of his 40 sections, namely sect. Cyclostigma and sect. Luntia. Below we discuss the pattern shown by the subsections and analyze each clade containing putative members of sect. Cyclostigma in the traditional sense. We also discuss the morphological patterns that could have misguided Webster and indicate morphological characters that separate these lineages with putative members of Cyclostigma s. 1. from members of sect. Cyclostigma s. s.

The Cyclostigma Clade (Section Cyclostigma s. s.)-Both $\operatorname{trnL}-F$ and ITS data allow us to identify a core monophyletic Cyclostigma clade. Although it is moderately supported by the ITS data $(70 \% \mathrm{BP}, 0.70 \mathrm{PP}$, Fig. 2), results from the trnL-F analysis give better support for this clade $(79 \% \mathrm{BP}$ and 1.00 PP, Fig. 1). The core Cyclostigma clade retained 21 species from our sampling of 48 species of sect. Cyclostigma s. 1. Most of the species in the Cyclostigma clade are medium to large-sized trees that produce red latex in the trunks and include the widely known "sangre de drago" or "sangre de grado" species. Other characters shared by these species are the basal bisexual cymules with pedicellate pistillate flowers, apetalous pistillate flowers (sometimes highly reduced, filament-like petals are present), bifid to quadrifid styles, staminate flowers with more than 16 stamens (a few species with more than 150), broad, palmately-veined leaves (usually with a cordate base), two or more petiolar glands, well developed stipules, and stellate pubescence (Figs. 3, 4). A recently discovered character for sect. Cyclostigma s. s. is the presence in secondary xylem of laticifers or specialized cells where latex is produced. In an extensive survey on the wood anatomy of Croton and of sect. Cyclostigma in particular, Wiedenhoeft et al. (2009) found that laticifers are unique to sect. Cyclostigma s. s., however it appears that not every species in the section bear laticifers and that the character could be polymorphic. Although none of these individual characters, with the exception of laticifers, are unique to the Cyclostigma clade, the presence of this suite of characters is unique to the clade. The species in this clade also have a preference for moist habitats, especially montane and riparian forests.

Of the four subsections of sect. Cyclostigma s. 1. (Table 1), only part of subsect. Palanostigma is retained in the Cyclostigma clade, besides the nominal subsect. Cyclostigma (Fig. 2). However, the type of subsect. Palanostigma (C. palanostigma), as well as several other members of this subsection, fall outside of the Cyclostigma clade. Most of these species belong to sect. Luntia, but C. warmingii Müll. Arg. belongs to sect. Cleodora, and C. goudotii belongs to the Old World clade. All species of subsect. Xalapenses belong to sect. Cascarilla, whereas members of subsect. Sampatik (C. cordiifolius Baill., C. piptocalyx Müll. Arg., C. organensis Baill., C. priscus Croizat, and C. sampatik Müll. Arg.) are distributed in four distantly related clades. This phylogenetic pattern clearly shows that Webster's subsectional division does not reflect the evolutionary relationship shown by ITS and trnL-F.

Section Cascarilla-Ten of the 48 sampled species of sect. Cyclostigma s. 1. were placed in a well supported clade with seven placeholders from sect. Cascarilla, which is one of the most species-rich lineages within Croton. Webster (2001) created a new subsection within sect. Cyclostigma (subsect.
Xalapenses) that included several species he considered aberrant within sect. Cyclostigma s. 1. because they lack the bisexual cymules at the base of the inflorescence and have sessile pistillate flowers. Our sampling included four species from subsect. Xalapenses (C. xalapensis, C. suberosus, C. chilensis, and C. pungens), and they all emerge in sect. Cascarilla along with five species formerly placed in subsect. Cyclostigma (C. abutiloides, C. aequatoris, C. gracilipes, C. ruizianus, and C. sarcopetalus) and one species (C. echioides Müll. Arg.) placed in subsect. Sampatik. Although some of these species have characters present in members of sect. Cyclostigma, none of the Cascarilla species share the same suite of characters defining sect. Cyclostigma s. s.

While examining morphological features in sections Cascarilla and Cyclostigma, we discovered a novel synapomorphy for sect. Cascarilla that supports its new molecular circumscription. The central columella of the capsule of Croton species usually remains after the dehiscence of the three cocci, and in most species of Croton it does not show any distinctive or special features. However, all members examined in sect. Cascarilla (including members of Webster's sect. Velamea, as synonymized in Berry et al. 2005) have three prominent terminal appendages on the columella that are usually ascending, with smooth, rounded and inflated ventral sides (Fig. 5). Section Cascarilla is the largest clade within Croton, and this synapomorphy is useful as a diagnostic character for the section. In addition, if other genetic markers besides ITS confirm sect. Cascarilla as the closest relative of the Cyclostigma clade, then this character is a key morphological difference separating these two lineages. The functional role of this character is unclear, but it may be involved in pollen tube growth or seed dispersal. Besides the shrubby habit and the distinct shape of the columella, most species in sect. Cascarilla differ from members of the Cyclostigma clade in the absence of bisexual cymules, sessile pistillate flowers, much smaller and narrower pistillate sepals, and their preference for dry or arid environments. From the examination of the morphology of the unsampled species of sect. Cyclostigma s. 1. from Table 1, we can predict that the following species will also be part of sect. Cascarilla: C. sarcopetaloides S. Moore, C. stenopetalus G. L. Webster, and C. boliviensis Müll. Arg. All these species are small shrubs with sessile pistillate flowers, bifid styles, stellate trichomes, and they all have the columella with the inflated distal appendages. Many taxa previously assigned to other Croton sections or unclassified species exhibit this morphology and are likely to be members of the Cascarilla clade.

Section Luntia-This group is a well supported clade $(100 \%$ BS, $1.00 \mathrm{BP})$ containing three putative species of sect. Cyclostigma s. 1. (C. chocoanus Croizat, C. smithianus Croizat, and C. palanostigma) (Fig. 2). Section Luntia sensu Webster included two subsections (Matourenses and Cuneati), with the type of the section (C. matourensis) belonging to subsection Matourenses. The type species of sect. Luntia subsect. Cuneati (C. cuneatus) is shown here to belong to a novel clade (the Cuneati clade in Figs. 1 and 2) that is not sister to subsection Matourenses. Consequently, sect. Luntia s. s. is composed of a mixture of species formerly from sect. Cyclostigma subsect. Palanostigma and members of sect. Luntia subsect. Matourenses (Webster 1993). In addition to C. megalodendron Müll. Arg. (included in this analysis), we have sampled C. matourensis Aubl. and C. skutchii Standl. from sect. Luntia subsect. Matourenses, and they form a monophyletic clade (van Ee 2006). Most members of sect. Luntia s. s. exhibit laminar 


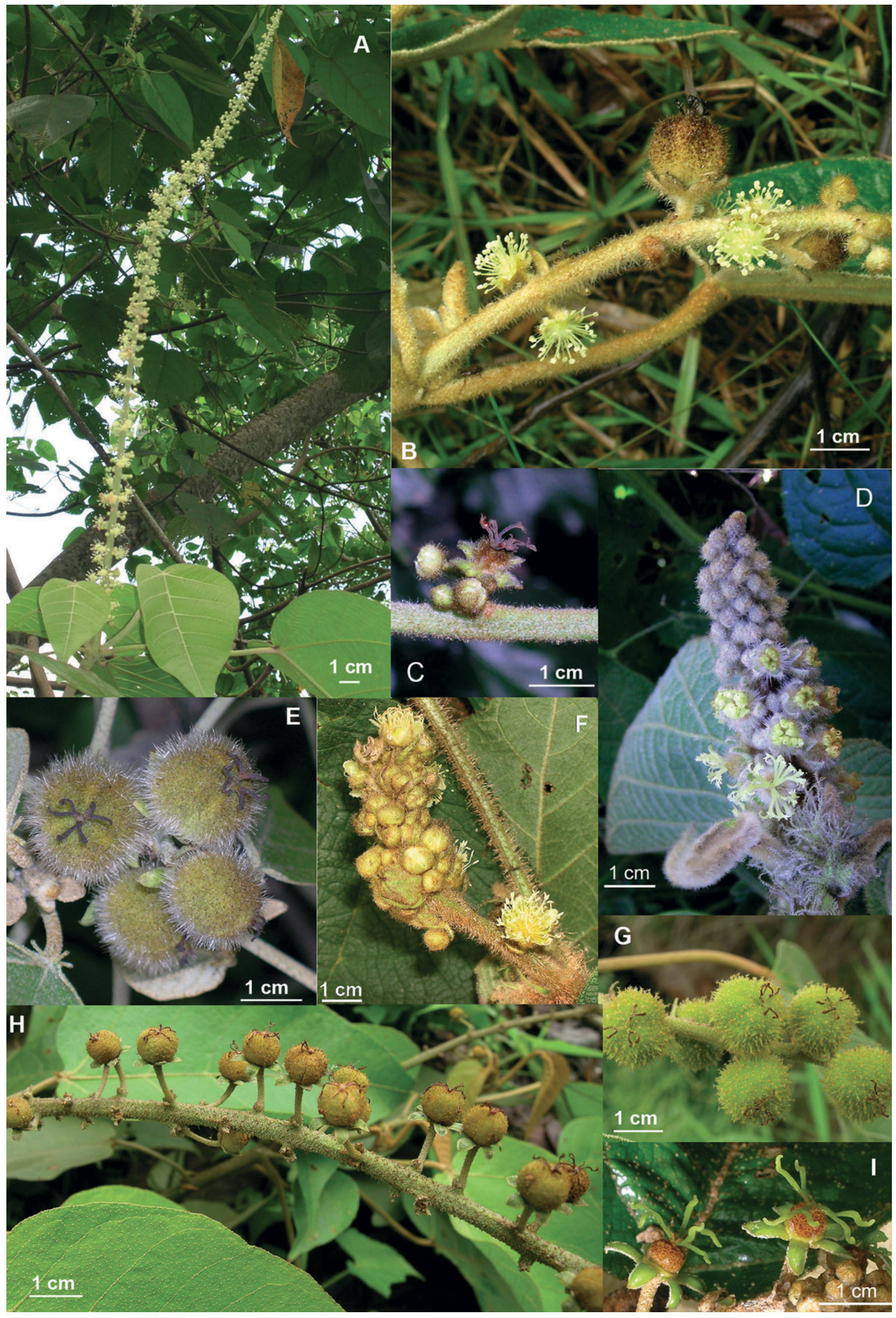

Fig. 3. Floral and fruit morphology of Croton sect. Cyclostigma s. s. A. Thyrsoid inflorescence (C. lechleri from Peru). B-C. Bisexual cymules and fruit (C. coriaceus). D. Quadrifid styles (C. perspeciosus). E. Fruits and bifid styles (C. piluliferus). F. One of the few examples of short inflorescences (C. medusae). G. Echinate-muricate fruits with bifid styles (C. echinocarpus). H. Long-pedicellate pistillate flowers / fruits with bifid styles (C. lechleri from Ecuador). I. Pistillate flowers with elongate, green bifid styles (C. floccosus). 


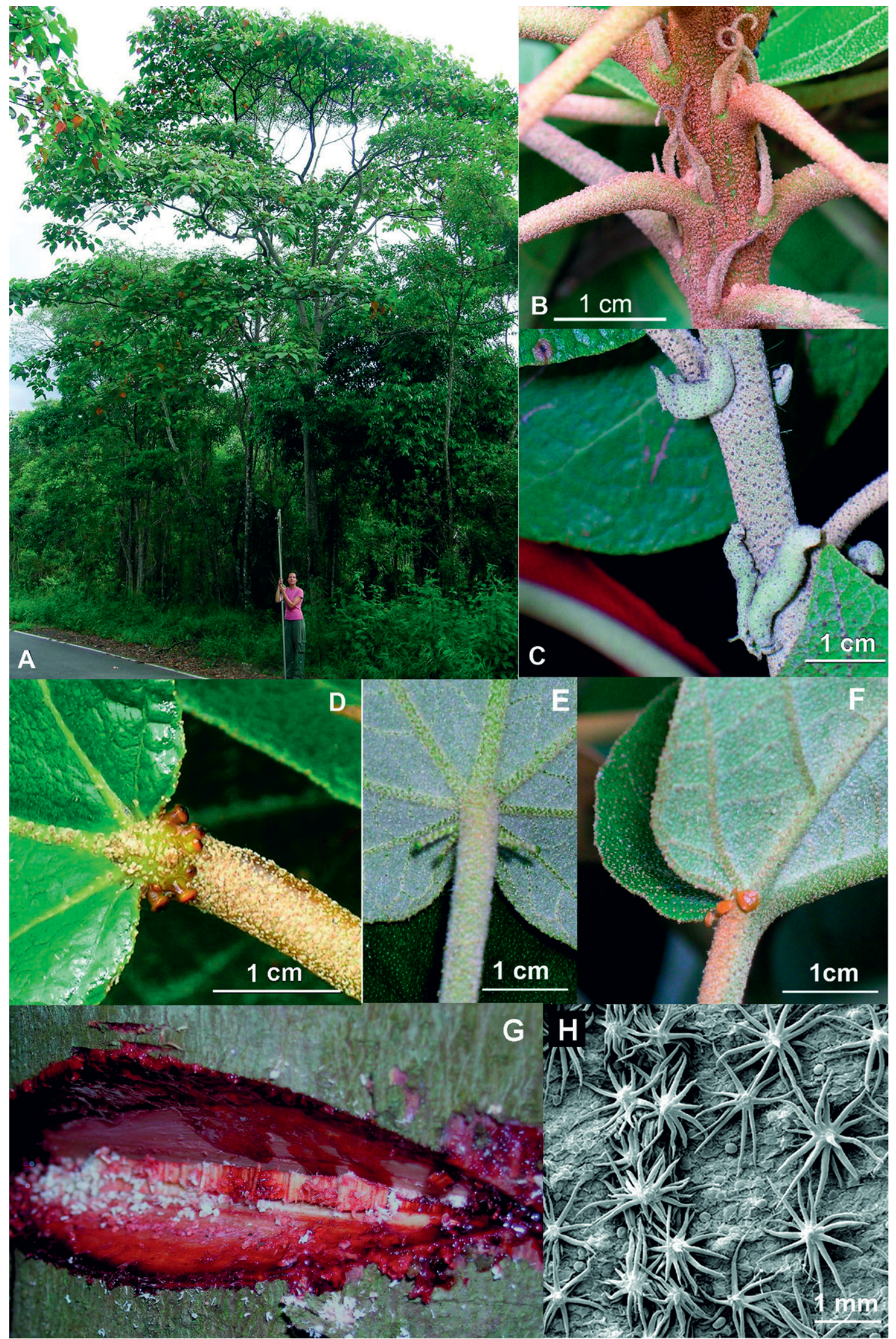

Fig. 4. Vegetative features shared by members of sect. Cyclostigma s. s. A. Arborescent habit (C. echinocarpus). B-C. Stipules in C. echinocarpus and C. piluliferus respectively. D-F. Petiolar glands (C. lechleri from Ecuador, C. piluliferus, and C. rimbachii). G. Red latex bleeding out of the trunk of C. macrobothrys. H. One of several types of stellate trichomes in sect. Cyclostigma. 

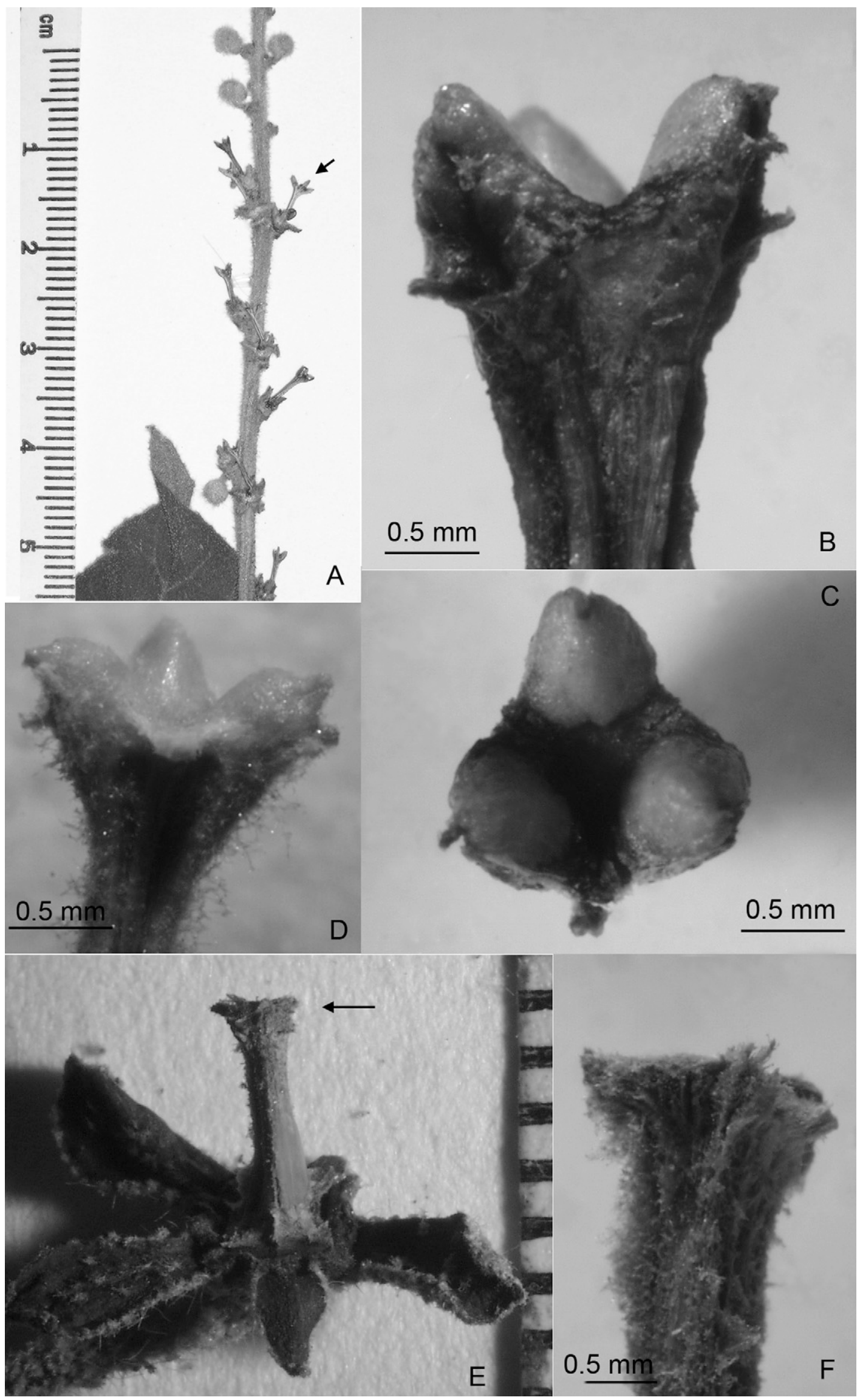

FIG. 5. Structure of the distal end of the columella of members of sect. Cascarilla (A-D), and sect. Cyclostigma s. s. (E-F). A. Mature inflorescence after fruit dehiscence showing the persistent columella (C. abutiloides). B-C. Two views of the distal end of the columella of C. pungens. D. Distal end of the columella of C. ruizianus. E-F. Columella of C. floccosus (sect. Cyclostigma s. s.) lacking the pronounced and inflated distal appendages typical of sect. Cascarilla. 
glands scattered on both surfaces of the leaves. They also share the arborescent habit, a combination of stellate and lepidote trichomes, petiolar glands, basal bisexual cymules, conspicuous bracts (3-4) subtending each cymule, 10-15 stamens, reduplicate calyces in both staminate and pistillate flowers (i.e. lobes that are strongly valvate, with the adjacent edges folding outwards into an obvious flange), and styles with 6-12 or more branches. Members of sect. Luntia s. s. differ from sect. Cyclostigma s. s. in the presence of laminar glands, lepidote trichomes, reduplicate calyces, fewer than 16 stamens, and 6-12-fid styles. Other species of sect. Cyclostigma s. 1. that we predict will be members of this clade based on morphological similarities are C. huitotorum Croizat, C. killipianus Croizat, and C. nuntians Croizat (Table 1).

Croton cordiifolius and Section Lamprocroton-Croton cordiifolius is a shrubby species from the coast of southeastern Brazil, and our phylogenetic analyses place it sister to sect. Lamprocroton (represented in our phylogeny by C. erythroxyloides Baill., C. pallidulus Baill., and C. troncosoi Ahumada). Croton cordiifolius is unusual in having axillary inflorescences (most Croton species have terminal inflorescences). In addition, the trnL-F sequence for this species has a $33 \mathrm{bp}$ deletion not shared with any other species of Croton sampled so far. Section Lamprocroton consists of around 20 species of small shrubs, all distributed in southeastern Brazil and northern Argentina. The MP analysis of $t r n L-F$ data is unable to resolve the phylogenetic position of $C$. cordiifolius, but both the ML and BA analyses of $\operatorname{trn} L-F$, and all analyses of ITS, place it sister to sect. Lamprocroton (Figs. 1, 2). When C. cordiifolius is analyzed in a different data set including all of the approximately 20 Lamprocroton species sampled to date, it comes out as the sister species to the entire clade (unpubl. data). Letícia Lima (pers. comm.), who studies sect. Lamprocroton, could not find any clear morphological similarity between C. cordiifolius and members of sect. Lamprocroton. The possibility exists that this relationship is an artifact of inadequate taxon sampling, a poor sequence due to low quality DNA (DNA was extracted from herbarium material), or it may be the result of long branch attraction. Croton cordiifolius was placed by Webster (1993) in sect. Cyclostigma subsect. Sampatik, due to the presence of inflorescences with bisexual cymules, bifid styles, petiolar glands, stellate trichomes, and pinnately veined leaves. However, it differs from sect. Cyclostigma s.s. in its shrubby habit, pinnately veined narrow leaves, absence of latex, and short axillary inflorescences. Additional sequence data from new samples of $C$. cordiifolius are needed to confirm the phylogenetic position of this species.

The Priscus Clade-Croton priscus was included by Webster in sect. Cyclostigma subsect. Sampatik (Table 1), and our data strongly support (99\% BS, and $1.00 \mathrm{BP}$ ) a novel clade including C. priscus and another species (C. eichleri Müll. Arg.) not assigned to any of the Webster's sections (Fig. 2). The third species in this clade is an undescribed species from southeastern Brazil (R. Riina unpubl. data). These three species share basal bisexual cymules, quadrifid styles, muricate fruits, pinnately veined leaves, petiolar glands, stellate-appressed trichomes, arborescent habit, reddish to colorless latex, and a southeastern Brazilian distribution. The species in the Priscus clade differ from members of the Cyclostigma clade in the pinnately veined leaves, crenate-dentate leaf margins with glands on the apex of the teeth, and pistillate flowers with large reduplicate sepals. In addition, their fruits are conspicuously muricate with stellate trichomes on the top of tall and thickened stalks. However, this fruit character has also evolved in one species of sect. Cyclostigma (C. echinocarpus Müll. Arg. also from southeastern Brazil).

Section Cleodora-Croton organensis and C. warmingii were placed by Webster in subsect. Sampatik and subsect. Palanostigma respectively (Table 1). Leaf venation was probably one character used by Webster to separate them into different subsections. Croton organensis has pinnate venation (a character defining subsect. Sampatik, Table 1), whereas the leaves of $C$. warmingii are palmately veined. Our results support these two species being part of a well supported clade $(78 \% \mathrm{BS}, 1.00 \mathrm{PP})$ that includes most of the members of Webster's sect. Cleodora, here represented by C. cajucara Benth. and C. hoffmannii Müll. Arg. Some characters shared by members of sect. Cleodora are arborescent habit, red to colorless latex, petiolar glands, basal bisexual cymules, 15-30 stamens, imbricate, accrescent, and sometimes fused pistillate sepals, quadrifid styles fused one half or three fourths of their length forming a tubular structure. Section Cleodora contains species with stellate trichomes as well as species with a dense silvery and/or a dark ferrugineous lepidote indumentum. There are also species with pinnately and palmately veined leaves. This group can be separated from sect. Cyclostigma by the presence of lepidote trichomes, pinnate venation, imbricate or fused pistillate sepals, and the characteristically connate styles forming a tubular structure.

The Old World Clade-Webster included eight species of Croton from the Old World in sect. Cyclostigma s. 1., six from continental Africa and four from Madagascar (Table 1). Our sampling was limited to three Malagasy species (C. mongue, C. oreades, and C. goudotii), all included in the ITS data set and one of them in both matrices (C. goudotii). Our ITS phylogeny indicates that the Malagasy species are not closely related to sect. Cyclostigma. We do not have molecular data showing that the African species C. draconopsis, C. congensis, and C. pynaertii, which were assigned by Webster (1993) to sect. Cyclosigma s. 1., do not belong there. However, Berry et al. (2005) recovered all 21 of the Old World species of Croton included in their sampling as a monophyletic group. Approximately 40 more Old World species have been sampled (unpubl. data) and they all belong to a monophyletic Old World clade. This suggests that the African species of sect. Cyclostigma s. 1. (C. draconopsis Müll. Arg., C. congensis De Wild., and C. pynaertii De Wild.) are a part of the Old World clade, following the pattern of the Malagasy taxa shown here. The Old World members of sect. Cyclostigma s. 1. have an overall resemblance to the Neotropical species of sect. Cyclostigma: they are trees with long inflorescences, bisexual cymules, multifid styles, petiolar glands, and stellate indumentum. However, the Malagasy species included by Webster in sect. Cyclostigma s. 1. all have conspicuous petals in the pistillate flowers, whereas species of sect. Cyclostigma s. s. either lack petals in the pistillate flowers or have them reduced to glandular filiform appendages. Another difference is the reduced length of the style branches in the Malagasy species, in contrast to the usually long style branches of sect. Cyclostigma s. s. Future molecular and morphological studies will need to take these African species into account to definitely confirm that sect. Cyclostigma is exclusively a New World lineage.

The Sampatik Clade-This clade includes two members of sect. Cyclostigma subsect. Sampatik, namely C. piptocalyx 
and C. sampatik, and one member (C. ater) of sect. Cyclostigma subsect. Cyclostigma (Table 1). Our phylogenetic results recovered these three species as a strongly supported monophyletic clade (Fig. 2). They are all large trees with colorless latex and are widespread in the Amazon basin up to the foothills of the Andes (C. sampatik, C. ater), and in the Mata Atlântica forests of southeastern Brazil (C. piptocalyx). They also share some characters present in sect. Cyclostigma: long inflorescences with basal bisexual cymules, bifid styles, and petiolar glands. They differ from sect. Cyclostigma, however, and resemble each other in the stellate (appressed)-lepidote trichomes, pinnately veined leaves, dentate leaf margins, stipitate glands on the abaxial surface of the lamina near the leaf margins, presence of horn-like nectaries in the staminate flowers, 15-20 stamens, deeply trilobed capsules, and the laterally compressed seeds with regular whitish spots on a dark brown background. The hornlike nectaries might be a synapomorphy for this clade, but the character needs to be examined more broadly within Croton. The petiolar glands in the species of the Sampatik clade might not be homologous to the petiolar glands of sect. Cyclostigma, since they differ in shape, size, and position on the petiole. Another species in this clade is C. sapiifolius Müll. Arg. from southeastern Brazil. Croton sapiifolius is the only member of Croton sect. Quadrilobus sensu Webster (1993), and is nearly unique within Croton in having tetramerous flowers and bilocular capsules. However, it resembles the three members of the Sampatik clade in the almost glabrous leaves with dentate-glandular margins, epipetiolar glands, similar stellate-lepidote trichomes, pinnately veined leaves, dentate leaf margins, absence of red latex, and bifid styles. van Ee et al. (2008) used a broader sampling of the basal lineages of Croton and recovered the species of the Sampatik clade along with C. pachypodus (included here as clade placeholder), C. megistocarpus J. A. González \& Poveda, and C. olivaceus Müll. Arg. as a grade in two alternative positions, either at the base of the core Croton clade (Clades C-2 to C-11 in Berry et al. 2005), or at the base of Croton subgenus Moacroton (Clade C-1 in Berry et al. 2005), represented in our sampling by sect. Corylocroton G. L. Webster. In the trnL-F analyses (Fig. 1), the Sampatik group is recovered as a grade leading up to sect. Corylocroton, the topology favored by van Ee et al. (2008), while in the ITS analyses (Fig. 2) it is recovered as a clade sister to sect. Corylocroton. However, this particular group of Croton needs additional molecular work because there are unsampled species from the Amazon region that show obvious morphological similarities with the Sampatik group (e.g. C. trombetensis R. de S. Secco, P. E. Berry \& N. A. Rosa, C. colombianus J. Murillo-A., and an undescribed species from French Guiana). Secco et al. (2001) described C. trombetensis and placed it in sect. Cyclostigma s. 1. We could not get sequence data from the few herbaium specimens known of this species, but an examination of its morphology suggests that it is more closely related to the Sampatik clade than to sect. Cyclostigma. Molecular phylogenetic analyses including this species are needed to test this morphologically based phylogenetic hypothesis.

Section Corylocroton-This section is represented in our sampling by $\mathrm{C}$. beetlei Croizat from the Chaco region of northeastern Argentina and southeastern Bolivia, C. caracasanus Pittier from northern South America, and C. lundellii Standl. from Mexico. Section Corylocroton is a mostly Central American-centered group of about 13 species with only

C. beetlei reaching far south into western South America. Section Corylocroton is very well supported by the molecular evidence as a monophyletic group (see van Ee 2006; van Ee et al. 2008). The Guatemalan Croton verapazensis, which is only known from the type specimen, was placed in sect. Cyclostigma s. 1. by Donnell Smith (1912), and Webster (1993) followed this placement. Species from sect. Corylocroton can be easily separated from sect. Cyclostigma by the absence of red latex, the presence of lepidote trichomes (sometimes along with sparse stellate trichomes), the lack of stipules, and the absence of bisexual cymules. Our results clearly show that $C$. verapazensis does not belong to sect. Cyclostigma, and is instead part of the well supported sect. Corylocroton.

The Sister Clade of Section Cyclostigma and Conflicting Gene Histories-Our results show that the ITS and chloroplast trnL $-F$ trees are discordant regarding the sister clade of sect. Cyclostigma and its phylogenetic position within Croton. ITS supports sect. Cascarilla as the sister group of sect. Cyclostigma (Fig. 2), whereas the trnL-F data place $C$. cupreatus as the sister clade (Fig. 1).

The first Croton molecular phylogeny published by Berry et al. (2005), using a combined data set of ITS and trnL-F, passed the ILD test only after removing two conflicting taxa (C. setiger Hook. and C. insularis Baill.). Nonetheless, that work included several representatives of both sections Cyclostigma s. s. (six species) and Cascarilla (13 species), but not C. cupreatus, and they recovered the same conflicting topologies between these two clades in their separate trnL-F and ITS analyses. One possible explanation for the differences in behavior of the ILD test with the present data set and the Croton data set from Berry et al. (2005) is that the test is sensitive to the number of taxa included from a given conflicting clade. We explored this idea by conducting a series of ILD tests (Table 2), and the results showed that sect. Cascarilla and the Cyclostigma clade are the main groups responsible for the incongruence in the data, and that $C$. cupreatus only plays a minor role. It is known that significant incongruence can be caused by convergent evolution or homoplasy on a tree, in addition to horizontal gene transfer (Planet 2006). There is also strong evidence that homoplasy increases as the number of taxa increases because there is more chance that two or more taxa will share a derived character state just by chance (Givnish and Sytsma 1997a,b; Sanderson and Donoghue 1989).

Three other chloroplast regions $r b c L, n d h F$ (van Ee et al. 2008), and matK (Riina 2006) show the same conflicting phylogenetic pattern, as expected. Unfortunately, these other plastid data sets did not include C. cupreatus, but current work is underway to obtain additional plastid sequence data from this species.

TABLE 2. Incongruence length difference tests (ILD) applied to the combined data set of ITS and trnL-F. All uninformative and gapped characters were removed. ( ${ }^{*}$ A significant $p$ value indicates that the two data partitions are incongruent).

Taxa excluded

0 (full data set)

Outgroup

Cascarilla clade + C. cupreatus

C. cupreatus

Cyclostigma s.s.

Cyclostigma s.s. + C. cupreatus

Cascarilla clade $p$ value (significant at 0.05 level) ${ }^{*}$

0.007

0.007

0.277

0.018

0.950

0.881

0.269 
Conflict among phylogenetic trees based on plastid genes (uniparentally inherited) and nuclear genes (biparentally inherited) is a common pattern in phylogenetic studies in angiosperms (see Rieseberg and Soltis 1991; Vriesendorp and Bakker 2005). These discrepancies among genes are attributed to events such as differential lineage sorting of ancestral polymorphisms in chloroplast and nuclear genes, evolutionary convergence or homoplasy, and ancient or recent hybridization and plastid capture (Sytsma 1990; Soltis and Kuzoff 1995; Comes and Abbott 2001; Doyle et al. 2003; Okuyama et al. 2005; Meerow et al. 2006). Taxon density, sampling error, and heterogeneous evolutionary rates (long branch attraction) have also been suggested as causal factors for phylogenetic incongruence (Soltis and Kuzoff 1995).

It is possible that Cyclostigma s. s. is the product of reticulate evolution and that it originated by an ancient hybridization event. But the phylogenetic pattern shown here could also be caused by any of the factors mentioned above. In order to better understand the evolutionary history of Cyclostigma s. s. we will need to explore multiple independent markers to corroborate this pattern, and information from morphology, karyology, ecology, and geography should be considered in future work with this group.

It is difficult to decide which gene phylogeny in this case is more concordant with morphology since it will require a detailed morphological survey across the genus. Even if we focus on the Cyclostigma clade and its sister clades from the two alternative phylogenies and compare them morphologically, it is hard to tell which one is closer to Cyclostigma. We find that Cascarilla seems more similar to Cyclostigma mainly because both of them have stellate pubescence, whereas $C$. cupreatus has a metallic lepidote indumentum both on vegetative and reproductive organs. However, C. cupreatus is a tree and has bisexual cymules with pedicellate pistillate flowers, three characters absent in members of sect. Cascarilla and present in sect. Cyclostigma s. s. Sections Cascarilla and Cyclostigma overlap in stamen number, whereas $C$. cupreatus does not $(<10)$. On the other hand, the molecular characters evaluated here show that the sister position of sect. Cyclostigma s. s. with either C. cupreatus (trnL-F) or Cascarilla (ITS) is well supported in both phylogenies, but it is possible that the relationship with $C$. cupreatus is an artifact of the taxon sampling. In addition, C. cupreatus is in a region of the tree where the majority of the backbone nodes have very low bootstrap support, so the association of $C$. cupreatus with the Cyclostigma clade might change when other taxa are included. More information from other markers is needed to better resolve this part of the phylogeny, and new taxon sampling using chloroplast sequences is necessary to determine if $C$. cupreatus remains as the immediate sister of sect. Cyclostigma in the chloroplast gene history.

In conclusion, the phylogenetic pattern resulting from ITS and trnL-F allow us to recircumscribe sect. Cyclostigma and identify a suite of morphological characters that characterize the group. This suite of characters is guiding us in finding new members of sect. Cyclostigma s. s. previously unplaced in Webster's (1993) classification, including new species (Riina et al. 2007). Ongoing work with additional molecular markers is focusing on the phylogenetic relationships within sect. Cyclostigma s. s., including these new members, as well as on the question of its phylogenetic placement within Croton. Finally, given the medicinal uses of the dragon's blood species (e.g. C. lechleri), our findings are relevant to future phar- macological studies on dragon's blood species as a tool to guide taxon sampling.

AcKnowledgments. This paper is part of the senior author's Ph.D. dissertation in the Department of Botany of the University of WisconsinMadison. We thank David Baum, Kenneth Sytsma, Alan W. Meerow, and two anonymous reviewers for useful comments and corrections. Financial support for this study was provided by the International Association of Plant Taxonomists (IAPT), the American Society of Plant Taxonomists (ASPT), the Latin American, Caribbean, and Iberian Studies at the University of Wisconsin-Madison (LACIS), the Department of Botany of the University of Wisconsin-Madison, the National Science Foundation (Grant No. DEB-0212481 to PEB), and the Hunt Institute for Botanical Documentation. The senior author is grateful to the staff of the following herbaria who helped her during field work in South America (AMAZ, GUAY, HOXA, IAN, INPA, LOJA, LPB, MG, MYF, PEUFR, QAP, QCNE, SP, SPF, USM, USZ, and VEN).

\section{Literature Cited}

Baillon, H. 1858. Étude générale du groupe des Euphorbiacées. Paris: Victor Masson.

Berry, P. E., A. L. Hipp, K. J. Wurdack, B. W. van Ee, and R. Riina. 2005. Molecular phylogenetics of the giant genus Croton and tribe Crotoneae (Euphorbiaceae sensu stricto) using ITS and trnL-trnF DNA sequence data. American Journal of Botany 92: 1520-1534.

Borges, J. R. and S. R. King. 2000. Croton lechleri, sustainable utilization of an Amazonian pioneer species. Medicinal Plant Conservation 6: 24-26.

Carrenho, R., V. L. R. Bononi, and L. M. Barbosa. 1997. Glomales em áreas de recomposição de mata ciliar de Moji-Guaçu, SP, Brasil. Hoehnea 24: 107-113.

Catalán, P., E. A. Kellogg, and R. G. Olmstead. 1997. Phylogeny of Poaceae subfamily Pooideae based on chloroplast $n d h F$ gene sequences. Molecular Phylogenetics and Evolution 8: 150-166.

Comes, H. P. and R. J. Abbott. 2001. Molecular phylogeography, reticulation, and lineage sorting in Mediterranean Senecio sect. Senecio (Asteraceae). Evolution 55: 1943-1962.

Donnell Smith, J. 1912. Undescribed plants from Guatemala and other Central American Republics. XXXV. Botanical Gazette 54: 235-244.

Doyle, J. J., J. L. Doyle, J. T. Rauscher, and A. H. D. Brown. 2003. Diploid and polyploid reticulate evolution through the history of the perennial soybeans (Glycine subgenus Glycine). The New Phytologist 161: $121-132$.

Farris, J. S., M. Kallersjo, A. G. Kluge, and C. Bult. 1994. Testing significance on incongruence. Cladistics 10: 315-319.

Givnish, T. J. and K. J. Sytsma. 1997a. Homoplasy in molecular vs. morphological data: the likelihood of correct phylogenetic inference. Pp. 55-101 in Molecular evolution and adaptive radiation, eds. T. J. Givnish and K. J. Sytsma. New York: Cambridge University Press.

Givnish, T. J. and K. J. Sytsma. 1997b. Consistency, characters, and the likelihood of correct phylogenetic inference. Molecular Phylogenetics and Evolution 7: 320-330.

Grisebach, A. H. R. 1859. Croton. Pp. 37-42 in Flora of the British West Indian Islands. London: L. Reeve.

Huelsenbeck, J. P. and F. Ronquist. 2001. MrBayes: Bayesian inference of phylogeny. Bioinformatics (Oxford, England) 17: 754-755.

Jones, K. 2003. Review of Sangre de Drago (Croton lechleri) -A South American tree sap in the treatment of diarrhea, inflamation, insect bites, viral infections, and wounds: traditional uses to clinical research. Journal of Alternative and Complementary Medicine (New York, N.Y.) 9: 877-896.

Lorenzi, H. 1992. Árvores brasileiras: manual de identificação e cultivo de plantas arbóreas nativas do Brasil, vol. 1. Nova Odessa: Editora Plantarum.

Maddison, D. R. and W. P. Maddison. 2001. MacClade 4.03: Analysis of Phylogeny and Character Evolution. Sunderland: Sinauer Associates.

Martin, D. and E. Rybicki. 2000. RDP: detection of recombination amongst aligned sequences. Bioinformatics (Oxford, England) 16: 562-563.

Maynard Smith, J. 1992. Analyzing the mosaic structure of genes. Journal of Molecular Evolution 34: 126-129.

Meerow, A. W., J. Francisco-Ortega, D. N. Kunth, and R. J. Schnell. 2006. Phylogenetic relationships and biogeography within the Eurasian clade of Amaryllidaceae based on plastid $n d h F$ and nrDNA ITS sequences: Lineage sorting in a reticulate area? Systematic Botany 31: $42-60$. 
Meza, E. N. 1999. Nombres aborígenes peruanos de las especies de Croton que producen el látex denominado "Sangre de Grado". Pp. 25-44 in Desarrollando nuestra diversidad cultural: "Sangre de Grado" y el reto de su producción en el Perú, ed. E. N. Meza, Lima: Fondo Editorial, Universidad Nacional Mayor de San Marcos.

Nylander, J. A. A. 2004. MrModeltest v2. Program distributed by the author. Uppsala: Department of Systematic Zoology, Uppsala University.

Okuyama, Y., N. Fujii, M. Wakabayashi, A. Kawakita, M. Ito, M. Watanabe, N. Murakami, and M. Kato. 2005. Nonuniform concerted evolution and chloroplast capture: heterogeneity of observed introgression patterns in three molecular data partition phylogenies of Asian Mitella (Saxifragraceae). Molecular Biology and Evolution 22: 285-296.

Padidam, M., S. Sawyer, and C. M. Fauquet. 1999. Possible emergence of new geminiviruses by frequent recombination. Virology 265: 218-225.

Planet, P. J. 2006. Tree disagreement: measuring and testing incongruence in phylogenies. Journal of Biomedical Informatics 39: 86-102.

Posada, D. and T. R. Buckley. 2004. Model selection and model averaging in phylogenetics: advantages of Akaike Information Criterion and Bayesian approaches over likelihood ratio tests. Systematic Biology 53: 793-808.

Posada, D. and K. A. Crandall. 1998. MODELTEST: testing the model of DNA substitution. Bioinformatics (Oxford, England) 14: 817-818.

Rambaut, A. 1996-2002. Sequence Alignment Editor v2.0a11. Oxford: University of Oxford.

Rieseberg, L. H. and D. E. Soltis. 1991. Phylogenetic consequences of cytoplasmic gene flow in plants. Evolutionary Trends in Plants 5: 65-84.

Riina, R. 2006. Molecular systematics of the neotropical dragon's blood trees Croton sect. Cyclostigma (Euphorbiaceae). Ph.D. Thesis. Madison: University of Wisconsin.

Riina, R., X. Cornejo, and P. E. Berry. 2007. A new species of "sangre de drago" (Croton section Cyclostigma, Euphorbiaceae) from coastal Ecuador. Brittonia 59: 97-101.

Sanderson, M. J. and M. J. Donoghue. 1989. Patterns of variation in levels of homoplasy. Evolution 43: 1781-1795.

Secco, R. S., P. E. Berry, and N. A. Rosa. 2001. Croton diasii and Croton trombetensis, two new Euphorbiaceae from Amazonian Brazil. Novon 11: 119-123.

Smith, B. A. 2002. A systematic revision of Croton section Cyclostigma (Euphorbiaceae) in Ecuador. Ph.D. Thesis. Davis: University of California.

Soltis, D. E. and R. K. Kuzoff. 1995. Discordance between nuclear and chloroplast phylogenies in the Heuchera group (Saxifragaceae). Evolution 49: 727-742.

Staden, R. 1996. The Staden Sequence Analysis Package. Molecular Biotechnology 5: 233-241.

Swofford, D. L. 2002. PAUP* Phylogenetic Analysis Using Parsimony (*and other methods), version 4.0b10. Sunderland: Sinauer Associates.

Sytsma, K. J. 1990. DNA and morphology: inference of plant phylogeny. Trends in Ecology \& Evolution 5: 104-110.

Taberlet, P., L. Gielly, G. Pautou, and J. Bouvet. 1991. Universal primers for amplification of three non-coding regions of chloroplast DNA. Plant Molecular Biology 17: 1105-1109.

Templeton, A. R. 1983. Phylogenetic inference from restriction endonuclease cleavage site maps with particular reference to the evolution of humans and the apes. Evolution 37: 221-244.

Ubillas, R., S. D. Jolad, R. C. Bruening, M. R. Kernan, S. R. King, D. F. Sesin, M. Barret, C. A. Stoddart, T. Flaster, J. Kuo, F. Ayala, E. Meza, M. Castañel, D. McMeekin, E. Rozhon, M. S. Tempesta, D. Barnard, J. Huffman, D. Smee, R. Sidwell, K. Soike, A. Brazier, S. Safrin, R. Orlando, P. T. M. Kenny, N. Berova, and K. Nakanishi. 1994. SP-303, an antiviral oligomeric proanthocyanidin from the latex of Croton lechleri (sangre de drago). Phytomedicine 1: 77-106.

Urbatsch, L. E., B. G. Baldwin, and M. J. Donoghue. 2000. Phylogeny of the coneflowers and relatives (Heliantheae: Asteraceae) based on nuclear rDNA internal transcribed spacer (ITS) sequences and chloroplast DNA restriction site data. Systematic Botany 25: 539-565.

van Ee, B. W. 2006. Molecular phylogenetics within Croton (Euphorbiaceae s. s.). Ph.D. Thesis. Madison: University of Wisconsin.

van Ee, B. W., P. E. Berry, R. Riina, and J. E. Gutiérrez Amaro. 2008. Molecular phylogenetics and biogeography of the Caribbeancentered Croton subgenus Moacroton (Euphorbiaceae s.s.). Botanical Review 74: 132-165.
Vriesendorp, B. and F. T. Bakker. 2005. Reconstructing patterns of reticulate evolution in angiosperms: what can we do? Taxon 54: 593-604

Webster, G. L. 1993. A provisional synopsis of the sections of the genus Croton (Euphorbiaceae). Taxon 42: 793-823.

Webster, G. L. 2001. Synopsis of Croton and Phyllanthus (Euphorbiaceae) in western tropical Mexico. Contributions From the University of Michigan Herbarium 23: 353-388.

White, T. J., T. Bruyns, S. Lee, and J. Taylor. 1990. Amplification and direct sequencing of fungal ribosomal RNA genes for phylogenetics. Pp. 315-324 in PCR protocols: a guide to methods and applications, eds. M. A. Innis, D. H. Gelfand, J. J. Sninsky, and T. J. White. San Diego: Academic Press.

Wiedenhoeft, A. C., R. Riina, and P. E. Berry. 2009. "Ray-intrusive" laticifers in species of Croton section Cyclostigma (Euphorbiaceae) may be non-articulated. IAWA Journal 30: 135-148.

Zwickl, D. J. 2006. Genetic algorithm approaches for the phylogenetic analysis of large biological sequence datasets under the maximum likelihood criterion. Ph.D. Thesis. Austin: The University of Texas.

APPENDIX1. Species sampled, voucher information (origin; collector, collector number and herbarium where specimen is deposited), and GenBank accession numbers (trnL-F; ITS, respectively; - = sequence missing)

Astraea lobata (L.) K1.; Brazil, Bahia; van Ee 486 (WIS); EU586999; EU586945. Brasiliocroton mamoninha P.E. Berry \& I. Cordeiro; Brazil, Espirito Santo; Pirani 4947 (SPF); EU586998; EU586944. Croton abutiloides Kunth; Ecuador, Tunguragua; Riina 1391 (WIS); EU586957; EU586903. C. aequatoris Croizat; Ecuador, Guayas; Riina 1431 (WIS); EU586956; EU586904. C. arboreus Millsp.; Mexico; van Ee 472 (WIS); EU497701; EU478029. C. astroites Dryand.; Puerto Rico; van Ee 537 (WIS); EU586955; EU586902. C. ater Croizat; Colombia, Boyacá; Lawrance 593 (TEX); -; EU586952. C. beetlei Croizat; Bolivia, Santa Cruz; Riina 1512 (WIS); EF408090; EU586916. C. cajucara Benth.; Brazil; Caruzo 95 (SP); EU586968; EU586913. C. caracasanus Pittier; Venezuela; Riina 1288 (VEN); DQ227557; DQ227525. C. cascarilla (L.) L.; Bahamas, Cat Island; Richey 99386 (MU); EU497707; EU477932. C. cascarilloides Raeusch; Thailand; Esser 20011 (M); AY971282; AY971191. C. celtidifolius Baill.; Brazil, Sao Paulo; Caruzo 32 (SP); EU586920; EU586975. C. chilensis Müll. Arg.; Chile; Quezada 313 (M); EU586959; EU586905. C. chocoanus Croizat; Ecuador, Esmeraldas; Riina 1415 (WIS); EU586995; EU586941. C. conduplicatus Kunth; Brazil; Lucena 598 (WIS); EU586963; EU477957. C. cordiifolius Baill.; Brazil, Bahia; Thomas 13601 (NY); EU586971; EU586917. C. coriaceus Kunth; Ecuador, Pichincha; Riina 1403 (WIS); EU586976; EU586921. C. cuneatus Kl.; Venezuela; Berry 7589 (WIS), Riina 1491 (WIS); AY794698; EU497735. C. cupreatus Croizat; Ecuador, Pichincha; Riina 1408 (WIS); EU586974; EU586919. C. curiosus Croizat; Argentina; Zuloaga 8438 (SI); EU586960; EU586906. C. discolor Willd.; Puerto Rico; van Ee 547 (WIS); EU497711; EU497736. C. draco Schltdl. \& Cham.; Costa Rica; van Ee 344 (WIS); EU586977; EU586954. C. draconoides Müll. Arg.; French Guiana, Saül; Phillippe 27019 (NY); EU586978; - . C. echinocarpus Müll. Arg.; Brazil, Minas Gerais; Riina 1371 (WIS); EU586979; EU586922. C. eichleri Müll. Arg.; Brazil, Rio de Janeiro; Riina 1525 (WIS); EU587001; EU586949. C. elegans Kunth; Ecuador; Berry 7675 (WIS); AY971296; AY971207. C. emporiorum Croizat; Bolivia; Wood 15844 (LPB); EU586961; EU586908. C. erythroxyloides Baill.; Brazil; Caruzo 74 (SP); EU586992; EU586938. C. floccosus B.A. Smith; Ecuador; Ceron 6909 (QCNE); EU586980; EU586923. C. glandulosepalus Millsp.; Belize; Vincent 6058 (MU); EU478126; EU477888. C. glandulosus L.; USA, Wisconsin; van Ee 512 (WIS); EU497713; EU478066. C. gossypiifolius Vahl; Venezuela; Mota sn (WIS); EU586981; EU586924. C. goudotii Baill.; Madagascar; Hoffmann 248 (K); EU587000; EU586946. C. gracilipes Baill.; Bolivia; Nee 47412 (NY); EU586962; EU586909. C. helicoideus Müll. Arg.; Bolivia; Wood 14086 (LPB); EU586956; EU586902. C. hibiscifolius Kunth ex Spreng.; Ecuador, Imbabura; Riina 1413 (WIS); EU586982; EU586925. C. hircinus Vent.; Venezuela; Riina 1291 (WIS); EU478127; EU477889. C. hirtus L'Her.; Brazil; Lima 345 (SPF); EU478160; EU478070. C. hoffmannii Müll. Arg.; Costa Rica; van Ee 598 (WIS); EF408111; EF421773. C. huberi Steyerm.; Venezuela, Miranda; Berry 7590 (WIS); AY971305; AY971217. C. lagoensis Müll. Arg.; Brazil, Minas Gerais; Warming 1653 (F); —; EU586926. C. lechleri Müll. Arg.; Peru, San Martin; Riina 1449 (WIS); EU586979; EU586927. C. lundellii Standl.; Mexico, Yucatán; Duran 3367; EF408101; EF421735. C. macrobothrys Baill.; Brazil, Rio de Janeiro; Riina 1522 (WIS); EU586984; EU586928. C. magdalenesis Müll. Arg.; Colombia; Arias 211 (NY); —; EU586929. C. medusae Müll. Arg.; Brazil; Carvalho 3789 (CEPEC); EU586988; EU586933. C. megalodendron Müll. Arg.; Venezuela, Miranda; Riina 1290 (WIS); EU586996; 
EU586942. C. pachypodus G.L. Webster; Costa Rica; Valverde 1043 (MO); EU587004; EU586953. C. mongue Baill.; Madagascar; Randrianairo 279 (MO); -; EU586947. C. mutisianus Kunth; Ecuador; Ceron 6188 (QCNE); EU586985; EU586930. C. niveus Jacq.; Costa Rica; van Ee 284 (WIS); EU478155; EU478046. C. oreades Leandri; Madagascar; Rakotomalaza 462 (K); -; EU586948. C. organensis Baill.; Brazil, Rio de Janeiro; Caruzo 90 (WIS); EU586969; EU586914. C. palanostigma K1.; Peru, Loreto; Riina 1492 (WIS); EU586997; EU586943. C. pallidulus Baill.; Brazil; Caruzo 31 (SP); EU586993; EU586939. C. perspeciosus Croizat; Peru, Pasco; Riina 1435 (WIS); EU586986; EU586931. C. piluliferus Britton ex Rusby; Bolivia, La Paz; Riina 1500 (WIS); EU586987; EU586932. C. piptocalyx Müll. Arg.; Brazil, Sao Paulo; Riina 1533 (WIS); EF408148; EF421790. C. priscus Croizat; Brazil, Sao Paulo; Riina 1535 (WIS); EU587002; EU586950. C. pungens Jacq.; Venezuela, Aragua; Riina 1272 (WIS); AY971326; AY971241. C. purdiaei Müll. Arg.; Colombia; Becerra 20 (NY); EU586989; EU586934. C. redolens Pittier; Venezuela; Gonzalez 4 (VEN); -; EU586935. C. rimbachii Croizat; Ecuador, Loja; Riina 1422 (WIS); EU586990; EU586936. C. roxburghii N.P. Balakr.; Thailand; Esser 9911 (WIS); AY971329; AY971244. C. ruizianus Müll. Arg.; Peru, Cusco; Riina 1487 (WIS); EU586964;
EU586910. C. saltensis Griseb.; Argentina; Zuloaga 8478 (SI); EU586965; EU586911. C. sampatik Müll. Arg.; Peru, Pasco; Riina 1447 (WIS); EF408133; EF421792. C. sapiifolius Müll. Arg.; Brazil, Bahia; Lima 667 (CEPEC); EF408150; EF421754. C. sarcopetalus Müll. Arg.; Argentina; Zuloaga 8600 (SI); EU586912; EU586966. C. schiedeanus Schltdl.; Costa Rica; Aguilar 886 (MO); AY971331; AY971246. C. smithianus Croizat; Costa Rica; Aguilar 2263 (MO); -; EU478101. C. sp. nova; Brazil, Bahia; Lima 654 (CEPEC); EU587003; EU586951. C. speciosus Müll. Arg.; Venezuela; Berry 7590 (WIS); EU478151; AY971251. C. suberosus Kunth; Mexico, Michoacan; Steinmann 1658 (IEB); EU478144; EU477979. C. troncosoi Ahumada; Argentina; Belgrano 423 (SI); EU586994; EU586940. C. urucurana Baill.; Brazil, Minas Gerais; Riina 1317 (WIS); EU586991; EU586937. C. verapazensis Donn.Sm.; Guatemala; Turkheim 2297 (GH); -; EF421750. C. verreauxii Baill.; Sidney Botanical Garden; Berry 7683 (WIS); AY971338; AY971257. C. warmingii Müll. Arg.; Brazil, Sao Paulo; Caruzo 56 (WIS); EU586970; EU586915. C. xalapensis Kunth; Mexico, Veracruz; Nee 29704 (NY); —; EU477987. C. yavitensis Croizat; Bolivia; Beck 5710 (LPB); EU586973; EU586918. C. gratissimus Burch.; Zambia: Songwe Gorge; Zimba 901 (MO); AY971341; AY971260. 